\title{
The effect of blinds on workplace illuminance
}

\author{
Jiri Vincenec ${ }^{1, *}$, and Martin Mitas ${ }^{1}$ \\ ${ }^{1}$ Tomas Bata University in Zlin, Faculty of Applied Informatics, Department of Automation and Control Engineering, Nad Stranemi 4511, \\ Zlin, Czech Republic
}

\begin{abstract}
The paper explores the effect of blinds on the workplace illuminance. The blinds are used to reduce solar load from the sunshine and decrease energy consumption for cooling in the overheated room. With blinds reducing inside illuminance the standards may not be fit and it is necessary add artificial lighting in this cases. It is important to correctly regulate daylight and eventually supplement it with artificial lighting to set the system for minimum energy consumption to meet all standard requirements. This paper presents the basic effect of the blinds on the internal illuminance of the workplace in the laboratory of lighting systems. This paper indicates that with increasing angles of blinds inside illuminance is decreasing.
\end{abstract}

\section{Introduction}

Nowadays, when electric energy is used almost in all areas, increased energy efficiency is required not only from electrical equipment but also from entire systems; for example, house automation.

For instance, to reduce solar load, it is necessary to regulate the glazing area. Hoffmann describes twelve different coplanar shade with different geometry. She presents a simulation of energy consumption in building with those different shades [1]. Daylight control can also be done with internal blinds. For example, Sanati divided the window into two parts, the upper part is equipped with fixed blind and the bottom part is equipped with blind, which can be controlled by the occupant [2]. Shen describes lighting and daylight control as one system; in other words, daylight control communicates with the lighting system and can communicate with HVAC system. His conclusion proves that less energy for lighting and cooling is needed when using integration [3]. The influence of shading control strategic describes Yun. He looked at the issue as a whole and include quantitative and qualitative criteria [4].

For optimal energy savings, it is also necessary to take into account the regulation of the light sources for the regulation of blinds. Roisin deals with lighting energy saving in office [5]. Similar approach presents Soori [6] with lighting strategy for a typical office building in Dubai, where he describes the impact of artificial lighting and natural lighting on the HVAC system. Caicedo demonstrates daylight-adaptive lighting control [7].

The purpose of this study is to describe blinds effect in the laboratory of lighting systems. In this case, we consider only quantitative parameters of inside illuminance at measuring points. Quantitative requirements are described in Czech stands [8,9]. Next phase of this research will contain artificial lighting and its automation with blinds to achieve optimal lighting conditions and energy consumption saving.

\section{Methods}

This article examines the effect of blinds on workplace illuminance in the laboratory that was built for the purpose of research on workplace lighting and home automation.

The laboratory is located at Tomas Bata University in Zlin, Faculty of Applied Informatics. GPS coordinates of the laboratory are $49^{\circ} 13^{\prime} 50^{\prime \prime}$ North latitude and $17^{\circ} 39^{\prime} 27^{\prime \prime}$ East longitude. The solar azimuth angle was set at $174^{\circ} 40^{\prime}$.

In the laboratory are six student workstations and one tutor workstation. The South wall is fitted with windows divided into smaller windows separated with inside pillars. These pillars are equipped with inside blinders.

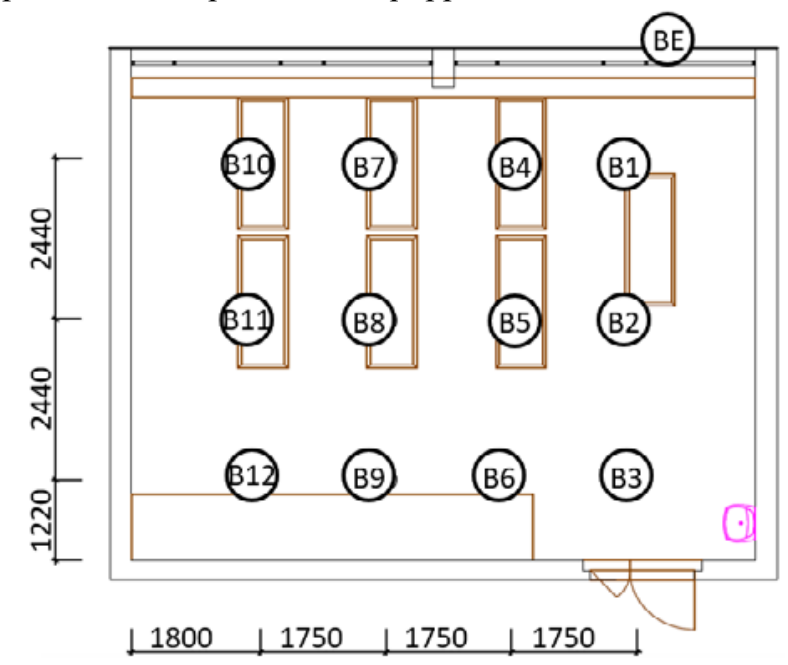

Fig. 1. The position of the measuring points in the room 
Outside the windows are equipped with outside blinders. These blinders are equipped with electric motors for automatic functions.

In the laboratory were set twelve checking point, the positions are shown in fig. 1 . Six checking points are at student's workstation, two at tutor workstation and the rest of the inside checking point near the inner wall. Outside illuminance is measured in front of the window position BE.

The measurement was supplemented by the calculation of the daily illumination level

$$
\begin{aligned}
& D=\frac{E}{E_{h}} \\
& \text { when } \begin{array}{lll}
D & \text { is } & \text { daylight factor [\%], } \\
E & & \text { inside illuminance [lx] } \\
E_{h} & \text { outside illuminance [lx]. }
\end{array}
\end{aligned}
$$

Two outdoor blinds can regulate daylight. Each blind can be controlled separately. Dimension and shape are shown in fig. 2. The blinder lamella angle can be set at an angle of $0^{\circ}$ to $75^{\circ}$.

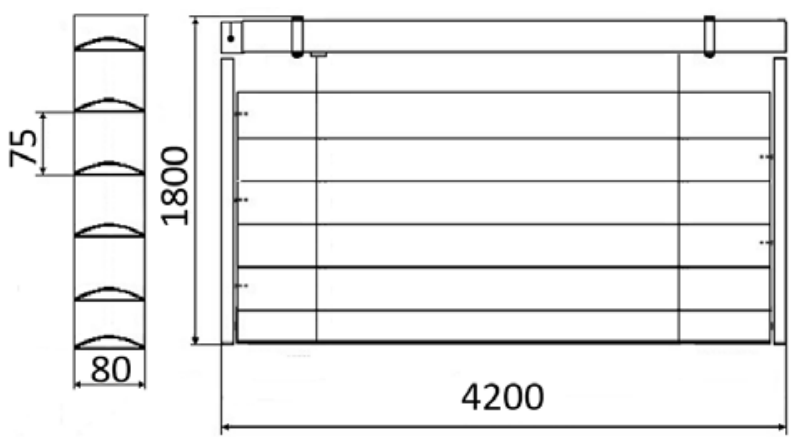

Fig. 2. Parameters of the blinds

For measurement were used data loggers Almemo and two measuring heads FLA $623 \mathrm{VL}$ with range 0 to $170 \mathrm{k} 1 \mathrm{x}$ and FLA603VL2 with range 0,05 to $12 \mathrm{k} 5 \mathrm{~lx}$. Both measuring heads with an absolute error less than $5 \%$.

\section{Results}

This article provides measurements of inside illuminance measured according to the checking points in the fig. 1 . Outside illuminance was measured at the same time as the measurement of inside illuminance.

The measurement was performed for cloudy sky without blinds and for clear sky without blinds and with blinds set on angles $90^{\circ}, 120^{\circ}$ and $165^{\circ}$. The angle is calculated from the horizontal plane.

\subsection{Daylight with cloudy sky}

The measurement was carried out 12. 4. 2017 between 11:15 and 11:30 with cloudy sky. With internal and external illumination were calculated daylight factor. Measured values and calculated daylight factor are in table 1. As can be seen outdoor illuminance during measurement is approximately nineteen thousands lux. When comparing daylight factor with standard values we can see that middle row meet minimal values for daylight factor and window row met average values for daylight factor. On the other hand, daylight factor at door row does not fit.

Table 1. Measured values with cloudy sky

\begin{tabular}{|c|c|c|c|}
\hline $\begin{array}{c}\text { Window } \\
\text { row }\end{array}$ & $\begin{array}{c}\text { Inside } \\
\text { illuminance } \\
{[\mathrm{lx}]}\end{array}$ & $\begin{array}{c}\text { Outdoor } \\
\text { illuminance } \\
{[\mathrm{lx}]}\end{array}$ & $\begin{array}{c}\text { Daylight } \\
\text { factor } \\
{[\%]}\end{array}$ \\
\hline Bod 1 & 2218 & 19489 & 11,38 \\
\hline Bod 4 & 2006 & 19262 & 10,41 \\
\hline Bod 7 & 1885 & 18545 & 10,16 \\
\hline Bod 10 & 1999 & 18581 & 10,76 \\
\hline $\begin{array}{c}\text { Middle } \\
\text { row }\end{array}$ & $\begin{array}{c}\text { Inside } \\
\text { illuminance } \\
{[1 \mathrm{x}]}\end{array}$ & $\begin{array}{c}\text { Outdoor } \\
\text { illuminance } \\
{[1 \mathrm{x}]}\end{array}$ & $\begin{array}{c}\text { Daylight } \\
\text { factor } \\
{[\%]}\end{array}$ \\
\hline Bod 2 & 621 & 19381 & 3,20 \\
\hline Bod 5 & 574 & 19187 & 2,99 \\
\hline Bod 8 & 510 & 18565 & 2,75 \\
\hline Bod 11 & 503 & 18386 & 2,73 \\
\hline $\begin{array}{c}\text { Door } \\
\text { row }\end{array}$ & $\begin{array}{c}\text { Inside } \\
\text { illuminance } \\
{[\mathrm{lx}]}\end{array}$ & $\begin{array}{c}\text { Outdoor } \\
\text { illuminance } \\
{[\mathrm{lx}]}\end{array}$ & $\begin{array}{c}\text { Daylight } \\
\text { factor } \\
{[\%]}\end{array}$ \\
\hline Bod 3 & 259 & 19346 & 1,34 \\
\hline Bod 6 & 245 & 18525 & 1,32 \\
\hline Bod 9 & 186 & 18861 & 0,99 \\
\hline Bod 12 & 195 & 18485 & 1,06 \\
\hline
\end{tabular}

\subsection{Daylight with clear sky}

The measurement was carried out 11. 4. 2017 between 11:00 and 13:00 with a clear sky. To determine the effect of daylight regulation several angles of the blind lamella.

The first measurement was performed for clear sky and no blinds. Measured values and calculated daylight factor are in table 2. As can be seen outdoor illuminance during measurement is approximately eighty-nine thousand lux. When comparing daylight factor with standard values we can see that in this case window row is under average values for daylight factor. For middle row, the values meet minimal values for daylight factor. On the other hand, daylight factor at door row is not fit satisfied.

Table 2. Measured values with clear sky and no blinds

\begin{tabular}{|c|c|c|c|}
\hline $\begin{array}{c}\text { Window } \\
\text { row }\end{array}$ & $\begin{array}{c}\text { Inside } \\
\text { illuminance } \\
{[\mathrm{lx}]}\end{array}$ & $\begin{array}{c}\text { Outdoor } \\
\text { illuminance } \\
{[\mathrm{lx}]}\end{array}$ & $\begin{array}{c}\text { Daylight } \\
\text { factor } \\
{[\%]}\end{array}$ \\
\hline Bod 1 & 4268 & 88556 & 4,82 \\
\hline Bod 4 & 3795,7 & 88590 & 4,28 \\
\hline Bod 7 & 3910,9 & 88785 & 4,40 \\
\hline Bod 10 & 4501,7 & 88918 & 5,06 \\
\hline $\begin{array}{c}\text { Middle } \\
\text { row }\end{array}$ & $\begin{array}{c}\text { Inside } \\
\text { illuminance } \\
{[1 \mathrm{x}]}\end{array}$ & $\begin{array}{c}\text { Outdoor } \\
\text { illuminance } \\
{[\mathrm{lx}]}\end{array}$ & $\begin{array}{c}\text { Daylight } \\
\text { factor } \\
{[\%]}\end{array}$ \\
\hline \multicolumn{3}{|c}{} \\
\hline
\end{tabular}




\begin{tabular}{|c|c|c|c|}
\hline Bod 2 & 1642,3 & 88619 & 1,85 \\
\hline Bod 5 & 1638,6 & 88604 & 1,85 \\
\hline Bod 8 & 1660,9 & 88534 & 1,88 \\
\hline Bod 11 & 1543,6 & 88312 & 1,75 \\
\hline $\begin{array}{c}\text { Door } \\
\text { row }\end{array}$ & $\begin{array}{c}\text { Inside } \\
\text { illuminance } \\
{[1 \mathrm{x}]}\end{array}$ & $\begin{array}{c}\text { Outdoor } \\
\text { illuminance } \\
{[1 \mathrm{x}]}\end{array}$ & $\begin{array}{c}\text { Daylight } \\
\text { factor } \\
{[\%]}\end{array}$ \\
\hline Bod 3 & 766,24 & 88748 & 0,86 \\
\hline Bod 6 & 772,41 & 88974 & 0,87 \\
\hline Bod 9 & 835,55 & 88543 & 0,94 \\
\hline Bod 12 & 713,72 & 87849 & 0,81 \\
\hline
\end{tabular}

The second measurement was performed for clear sky and blinds set at $90^{\circ}$. Measured values and calculated daylight factor are in table 3 . As can be seen outdoor illuminance during measurement is approximately eighty-nine thousand lux. When comparing daylight factor with standard values we can see that in this case window row is under minimal values for daylight factor. For middle and door row, the values do not meet minimal values for daylight factor.

Table 3. Measured values with clear sky and tilt of blinds $90^{\circ}$

\begin{tabular}{|c|c|c|c|}
\hline $\begin{array}{c}\text { Window } \\
\text { row }\end{array}$ & $\begin{array}{c}\text { Inside } \\
\text { illuminance } \\
{[\mathrm{lx}]}\end{array}$ & $\begin{array}{c}\text { Outdoor } \\
\text { illuminance } \\
{[\mathrm{lx}]}\end{array}$ & $\begin{array}{c}\text { Daylight } \\
\text { factor } \\
{[\%]}\end{array}$ \\
\hline Bod 1 & 1158 & 89114 & 1,30 \\
\hline Bod 4 & 1035 & 90020 & 1,15 \\
\hline Bod 7 & 1000 & 89362 & 1,12 \\
\hline Bod 10 & 1138 & 89302 & 1,27 \\
\hline $\begin{array}{c}\text { Middle } \\
\text { row }\end{array}$ & $\begin{array}{c}\text { Inside } \\
\text { illuminance } \\
{[1 \mathrm{x}]}\end{array}$ & $\begin{array}{c}\text { Outdoor } \\
\text { illuminance } \\
{[1 \mathrm{x}]}\end{array}$ & $\begin{array}{c}\text { Daylight } \\
\text { factor } \\
{[\%]}\end{array}$ \\
\hline Bod 2 & 643 & 89629 & 0,72 \\
\hline Bod 5 & 617 & 89681 & 0,69 \\
\hline Bod 8 & 617 & 89203 & 0,69 \\
\hline Bod 11 & 568 & 89927 & 0,63 \\
\hline $\begin{array}{c}\text { Door } \\
\text { row }\end{array}$ & $\begin{array}{c}\text { Inside } \\
\text { illuminance }\end{array}$ & $\begin{array}{c}\text { Outdoor } \\
\text { illuminance } \\
{[\mathrm{lx}]}\end{array}$ & $\begin{array}{c}\text { Daylight } \\
\text { factor } \\
{[\%]}\end{array}$ \\
\hline Bod 3 & 323 & 89528 & 0,36 \\
\hline Bod 6 & 320 & 89864 & 0,36 \\
\hline Bod 9 & 355 & 89189 & 0,40 \\
\hline Bod 12 & 238 & 89639 & 0,27 \\
\hline
\end{tabular}

The third measurement was performed for clear sky and blinds set at $120^{\circ}$. Measured values and calculated daylight factor are in table 4 . As can be seen outdoor illuminance during measurement is approximately eighty-seven thousand lux. When comparing daylight factor with standard values we can see that no values of daylight are fulfilled.

Table 4. Measured values with clear sky and tilt of blinds $120^{\circ}$

\begin{tabular}{|c|c|c|c|}
\hline $\begin{array}{c}\text { Window } \\
\text { row }\end{array}$ & $\begin{array}{c}\text { Inside } \\
\text { illuminance } \\
{[\mathrm{lx}]}\end{array}$ & $\begin{array}{c}\text { Outdoor } \\
\text { illuminance } \\
{[\mathrm{lx}]}\end{array}$ & $\begin{array}{c}\text { Daylight } \\
\text { factor } \\
{[\%]}\end{array}$ \\
\hline
\end{tabular}

\begin{tabular}{|c|c|c|c|}
\hline Bod 1 & 678 & 86458 & 0,78 \\
\hline Bod 4 & 639 & 87248 & 0,73 \\
\hline Bod 7 & 552 & 87348 & 0,63 \\
\hline Bod 10 & 586 & 87387 & 0,67 \\
\hline $\begin{array}{c}\text { Middle } \\
\text { row }\end{array}$ & $\begin{array}{c}\text { Inside } \\
\text { illuminance } \\
{[1 \mathrm{x}]}\end{array}$ & $\begin{array}{c}\text { Outdoor } \\
\text { illuminance } \\
{[1 \mathrm{x}]}\end{array}$ & $\begin{array}{c}\text { Daylight } \\
\text { factor } \\
{[\%]}\end{array}$ \\
\hline Bod 2 & 346 & 86807 & 0,40 \\
\hline Bod 5 & 329 & 87288 & 0,38 \\
\hline Bod 8 & 311 & 87106 & 0,36 \\
\hline Bod 11 & 298 & 87095 & 0,34 \\
\hline $\begin{array}{c}\text { Door } \\
\text { row }\end{array}$ & $\begin{array}{c}\text { illuminance } \\
{[1 \mathrm{x}]}\end{array}$ & $\begin{array}{c}\text { Outdoor } \\
\text { illuminance } \\
{[1 \mathrm{x}]}\end{array}$ & $\begin{array}{c}\text { Daylight } \\
\text { factor } \\
{[\%]}\end{array}$ \\
\hline Bod 3 & 192 & 87300 & 0,22 \\
\hline Bod 6 & 187 & 87567 & 0,21 \\
\hline Bod 9 & 204 & 87217 & 0,23 \\
\hline Bod 12 & 139 & 87266 & 0,16 \\
\hline
\end{tabular}

The last measurement was performed for clear sky and blinds set at $165^{\circ}$, which is the maximum angle and represents the maximum shade blinds. Measured values and calculated daylight factor are in table 5. As can be seen outdoor illuminance during measurement is approximately ninety thousand lux. When comparing daylight factor with standard values we can see that in this case none of the measured points fulfils standard values.

Table 5. Measured values with clear sky and tilt of blinds $165^{\circ}$

\begin{tabular}{|c|c|c|c|}
\hline $\begin{array}{c}\text { Window } \\
\text { row }\end{array}$ & $\begin{array}{c}\text { Inside } \\
\text { illuminance } \\
{[\mathrm{lx}]}\end{array}$ & $\begin{array}{c}\text { Outdoor } \\
\text { illuminance } \\
{[\mathrm{lx}]}\end{array}$ & $\begin{array}{c}\text { Daylight } \\
\text { factor } \\
{[\%]}\end{array}$ \\
\hline Bod 1 & 58 & 90424 & 0,06 \\
\hline Bod 4 & 58 & 89958 & 0,06 \\
\hline Bod 7 & 55 & 90062 & 0,06 \\
\hline Bod 10 & 55 & 90098 & 0,06 \\
\hline $\begin{array}{c}\text { Middle } \\
\text { row }\end{array}$ & $\begin{array}{c}\text { Inside } \\
\text { illuminance } \\
{[1 \mathrm{x}]}\end{array}$ & $\begin{array}{c}\text { Outdoor } \\
\text { illuminance } \\
{[1 \mathrm{x}]}\end{array}$ & $\begin{array}{c}\text { Daylight } \\
\text { factor } \\
{[\%]}\end{array}$ \\
\hline Bod 2 & 26 & 89797 & 0,03 \\
\hline Bod 5 & 25 & 90155 & 0,03 \\
\hline Bod 8 & 24 & 90236 & 0,03 \\
\hline Bod 11 & 23 & 89809 & 0,03 \\
\hline $\begin{array}{c}\text { Door } \\
\text { row }\end{array}$ & $\begin{array}{c}\text { Inside } \\
\text { illuminance }\end{array}$ & $\begin{array}{c}\text { Outdoor } \\
\text { illuminance } \\
{[1 \mathrm{x}]}\end{array}$ & $\begin{array}{c}\text { Daylight } \\
\text { factor } \\
{[\%]}\end{array}$ \\
\hline Bod 3 & 13 & 90437 & 0,01 \\
\hline Bod 6 & 12 & 90487 & 0,01 \\
\hline Bod 9 & 12 & 90292 & 0,01 \\
\hline Bod 12 & 9 & 90368 & 0,01 \\
\hline
\end{tabular}

Fig. 4 show inside illuminance for blinds angle $90^{\circ}, 120^{\circ}$ and $165^{\circ}$. In this figure can be seen, that requirement for the illuminance of working place are fulfilled for angle $90^{\circ}$ window row and middle row and for angle $120^{\circ}$ is this requirement fulfilled for window row. The rest of values does not fit the standard requirements and they should be completed with artificial lighting. 


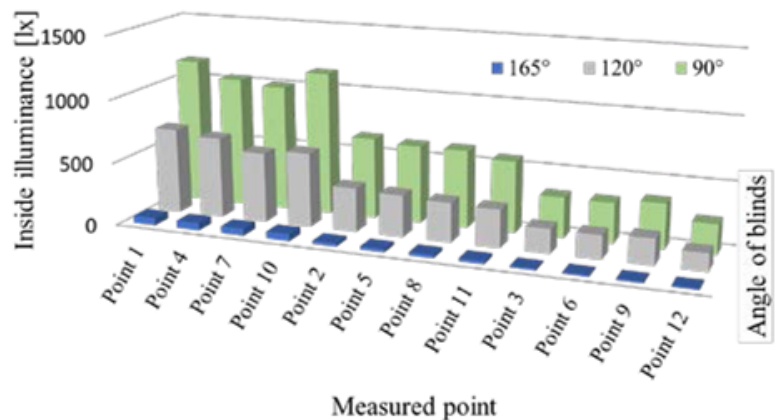

Fig. 3. Inside illuminance for blinds angle $90^{\circ}, 120^{\circ}$ and $165^{\circ}$

\section{Conclusion}

This paper describing the effect of blinds on workplace illuminance. Table 1 presents illuminance levels at 12 checking point in the laboratory without the blinders with cloudy sky. Both requirements, illuminance of workspace and daylight factor are fulfilled.

Table 2 shows illuminance levels for clear sky and no blinders. As can be seen, the illuminance of the workspace is meet for all measured points, but daylight requirement is fulfilled only for window and middle row. The disadvantage of this solution is that solar load will enormously burden inside temperature and direct sunlight will cause glare.

To eliminate solar load and glare the blinders could be used. This article provides basic measurement of blinds angle on internal illuminance. The angle was set at $90^{\circ}, 120^{\circ}$ and $165^{\circ}$, which present maximal shading.

Measured values of those angles are in tables 3, 4 and 5. As can be seen, daylight factor is not fulfilled except for angle $90^{\circ}$ window row, when values meet with minimal daylight factor. On the other hand, workplace illuminance is fulfilled for angle $90^{\circ}$ window and middle row and for angle $120^{\circ}$ window row. This fact is also evident from the figure 4 .
This study deals only with internal illuminance and it does not adequately reflect solar load savings. The main goal was to map the effect on the internal illuminance. The next step in this research is measured artificial lighting and program optimal control for combination of daylight and artificial lighting because when optimal daylight and artificial lighting is set the solar load is reduced at the minimum and inner illuminance is completed with artificial lighting.

This work was supported by the European Regional Development Fund under the project CEBIA-Tech No. CZ.1.05/2.1.00/03.0089 and also by the Internal Grant Agency of Tomas Bata University under the project No. IGA/CebiaTech/2017/002 .

\section{References}

1. S. Hoffmann, E. S. Lee, A. McNeil, L. Fernandes, D. Vidanovic, A. Thanachareonkit, Energy and Buildings 112, 19 (2019)

2. L. Sanati, M. Utzinger, Building and Environment 64, 10 (2013)

3. E. Shen, J. Hu, M- Patel, Building and Environment 78, 15 (2104)

4. G. Yun, K. Ch. Yoon, K. S. Kim, Energy and Buildings 84, 15 (2014)

5. B. Roisin, M. Bodart, A. Deneyer, P. D'Herdt, Energy and Buildings 40, 10 (2008)

6. P. K. Soori, M. Vishwas, Energy and Buildings 66, 9 (2013)

7. D. Caicedo, A. Pandharipande, F. M. J. Willwms, Energy and Buildings 73, 10 (2014)

8. CSN 73 0580-1, Standard, Czech office for standards, metrology and testing, Prague, CZ (2012)

9. CSN EN 12464-1, Standard, Czech office for standards, metrology and testing, Prague, CZ (2012) 